\title{
Comparison of Two Different Methods of Average Working Length Determination in Second Molars and Premolars
}

\author{
Comparación de Dos Métodos para Determinar la Longitud de \\ Trabajo Promedio en Segundos Molares y Premolares
}

\author{
Cynthia Rodríguez-Niklitschek,***; Mario Cantín ${ }^{*, * *, * * * * *}$ \& Oporto, V. G. H.**,******
}

RODRÍGUEZ-NIKLITSCHEK, C.; CANTÍN, M. \& OPORTO, V. G. H. Comparison of two different methods of average working length determination in second molars and premolars. Int. J. Morphol., 33(3):1136-1140, 2015.

SUMMARY: Within the procedures involved in a successful endodontic treatment is the working length (WL) determination. The root canal end must be detected accurately, and a precise control of the WL must be maintained. There are several methods to determine WL. Researchers have published the average teeth length (ATL) to the human permanent dentition. These measurements are used as an anatomical reference. If the WL is evaluated using a radiographic image, it is accepted as clinical success if the limit of the canal sealing is $1 \mathrm{~mm}$ coronal to the root apex. One method to determine WL is based in substract $1 \mathrm{~mm}$ to ATL. Another method widely used, assert to achieve a more precise WL determination, through the use of an electronic apex locator (AL). Nevertheless, published measures of ATL are still used as anatomical reference, and are used to determine WL in the absence of an AL. The aim of this study was to determine the average WL of second molars and premolars with endodontic treatment indication using a PropexII® AL, and compare these measurements to WL determination using ATL method. A descriptive cross-sectional study with a non-random sample of consecutive cases was executed. Results showed that there were no statistically significant differences between the WL obtained with AL and ATL method in studied teeth, except mesio-buccal canal of second maxillary molars (19.94 mm average using AL, $1.54 \mathrm{~mm}$ greater than ATL method $18.40 \mathrm{~mm} ; \mathrm{p}=0.002$ ). The ATL method to determine WL could be used to determine the WL of second molars and premolars in studied population. Further research should be performed to determine if ATL method is safe and reliable to be used in absence of an AL or in patients where this instrument cannot be used.

KEY WORDS: Endodontics; Electronic apex locator; Working length; Root canal system anatomy.

\section{INTRODUCTION}

The primary objective of endodontics is to prevent and treating pulpal and periodontal lesions, providing dental substrate to restore lost shape and function through oral rehabilitation. Endodontic treatment (ET) includes several stages. One of them is the determination of the root canal working length (WL), considered one of the most important steps in ET (Ozsezer et al., 2007). WL is the distance from a coronal point to the site where the preparation and obturation of the root canal ends. WL must be accurate and reliable because it directly influences the success of therapy (Pereira et al., 2014). A wrong WL determination could lead into a long or short measure, which may bring to the occurrence of accidents during ET, postoperative pain and a delayed periapical repair (Ozsezer et al.). The WL must be defined using anatomical parameters. Cemento-dentinal Junction (CDJ) is the most apical point of the dental pulp, where dentin ends and canal continue with cement walls. The WL should end closer to this point, preferably at the apical constriction (AC) (Martins et al., 2014). AC is the root canal area with the smaller diameter, and it represents the junction between pulpal and periodontal tissues (Jarad et al., 2011; Abarca et al., 2014). Even though CDJ may or may not coincide with AC; AC must be the limit of canal preparation and root filling, because this zone offers the best histological conditions for apical reparation (Pereira et al.). CDJ cannot be identified clinically (Somma et al., 2012). Usually the WL is radiographically determined (McDonald \& Hovland, 1990; Shanmugaraj et al., 2007),

\footnotetext{
* Programa de Magíster en Odontología, Facultad de Odontología, Universidad de La Frontera, Temuco, Chile.

*** Escuela de Odontología, Cátedra de Endodoncia, Universidad Mayor Sede Temuco, Temuco, Chile.

**** Departamento de Odontología Integral Adultos y CEMyQ, Facultad de Odontología, Universidad de La Frontera, Temuco, Chile.

***** Center of Research in Biomedical Sciences, Universidad Autónoma de Chile, Temuco, Chile.

***** Centro de Biología Molecular y Farmacogenética, Departamento de Ciencias Básicas, Facultad de Medicina, Universidad de La Frontera, Temuco, Chile.
} 
however the radiographic image only shows the apex location but does not show the AC (Ozsezer et al.; Jarad et al.; Shanmugaraj et al.), and depends of the dentist's ability to interpret radiographic images (Martins et al.).

Accurate knowledge of the root canal system anatomy is essential to perform a successful endodontic treatment (Abella et al, 2012). Ingle \& Bakland (2004) published the average teeth length (ATL) of the human permanent dentition. These parameters are currently accepted as anatomical references. Due to anatomical variations in the apical third of the root canal, it is accepted as clinical success if endodontic preparation and obturation end $1 \mathrm{~mm}$ coronal to the radiographic root apex.

Several methods have been described to determine WL. One of them considers most of the points just reviewed; it is based on the ATL data published by Ingle $\&$ Bakland, $1 \mathrm{~mm}$ must be subtracted from those measurements. Another method determines WL using an electronic apex locator (AL). There is a consensus regarding $\mathrm{AL}$ as a tool that allows more precise and reliable measurements. The main advantage of AL is its ability to measure the length of root canal to the end of the CDJ close to AC (Martins et al). Nevertheless characteristics of AL, ATL measures are still used as an anatomical reference, as well as ATL-based method to determine WL is actually used nowadays. Interestingly, there are no studies that evaluate whether WL determined using ATL are consistent with WL obtained through AL. Finally, research published by Ingle \& Bakland were made in Caucasian people, and there are not information available supporting the use of ATL in non-Caucasian individuals.

The aim of this study was to determine the average WL in root canals of second molars and premolars using $\mathrm{AL}$, and compare it to WL determination using ATL data published by Ingle \& Bakland in Chilean individuals.

\section{MATERIAL AND METHOD}

This study was approved by the Institutional Ethics Committee of the Universidad Mayor, Chile (Protocol N ${ }^{\circ} 10 /$ 2013). A descriptive cross-sectional study with a non-random sample of consecutive cases was executed. The sample consisted of male and female patients, aged 18 years old, in treatment at endodontics teaching clinic, Universidad Mayor, Sede Temuco. Individuals included in this research needed ET in second molars and second premolars. Treatments were performed from March 2011 to December 2012. Informed consent was obtained from all those participating.

Second molars and premolars were included with three and one root canal respectively, it was required that teeth crown were conserved, and root apex be entirely developed. We excluded teeth with conditions such as metal restorations, dental crowns, root canal obliteration, tooth wear, teeth that could not be isolated using rubber dam, teeth previously pulpectomized and patients with pacemakers. AL measurements were taken using PropexII® (DentsplyMaillefer, Ballaigues, Switzerland) and were performed by a single operator, according to PropexII® manufacturer's protocol.

Each tooth was isolated using rubber dam, and trepanation was performed. The access was prepared, and pulp canals were explored using a sterile size $15 \mathrm{~K}$-file (DentsplyMaillefer, Ballaigues, Switzerland) according to radiographic root length. Subsequently, pulp tissue was partially removed, and the root canals were debrided and irrigated with sodium hypochlorite $5.25 \%$. After aspiration of fluid excess, ProPexII® AL was used to determine the WL of roots canals according to manufacturer's protocol. Measurements were confirmed using a conventional periapical radiography. If was detected that K-file exceeded the root apex, the measurement was performed again until it was correct.

Table I. Measures of average total length (ATL) and reference average working length (ATL - $1 \mathrm{~mm}$ ) of seconds premolars and molars, according published data by Ingle \& Bakland.

\begin{tabular}{|c|c|c|c|c|c|}
\hline Tooth & Root canal & $\begin{array}{l}\text { ATL } \\
(\mathbf{m m})\end{array}$ & $\begin{array}{c}\text { Maximum } \\
\text { length }(\mathrm{mm})\end{array}$ & $\begin{array}{c}\text { Minimum } \\
\text { length }(\mathrm{mm})\end{array}$ & $\begin{array}{c}\mathbf{A T L}-1 \mathrm{~mm} \\
(\mathbf{m m})\end{array}$ \\
\hline Maxillary $2 \mathrm{n}^{\mathrm{d}}$ premolar & Single canal & 21 & 23 & 19 & 20 \\
\hline Mandibular $2^{\text {nd }} p_{\text {remolar }}$ & Single canal & 21.4 & 23.7 & 19.1 & 20.4 \\
\hline \multirow[t]{3}{*}{ Maxillary $2 \mathrm{n}^{\mathrm{d}}$ molar } & MB & 20.2 & 22.2 & 18.2 & 19.2 \\
\hline & DB & 19.4 & 21.3 & 17.5 & 18.4 \\
\hline & $\mathrm{P}$ & 20.8 & 22.6 & 19.0 & 19.8 \\
\hline \multirow[t]{3}{*}{ Mandibular $2^{\text {nd }} \mathrm{m}_{\text {olar }}$} & MB & 20.9 & 22.6 & 19.2 & 19.9 \\
\hline & ML & 20.9 & 22.6 & 19.2 & 19.9 \\
\hline & $\mathrm{D}$ & 20.8 & 22.6 & 19.0 & 19.8 \\
\hline
\end{tabular}

Abbreviations: $\mathrm{D}=$ Distal; $\mathrm{DB}=$ Disto buccal; $\mathrm{MB}=$ Mesio buccal; $\mathrm{ML}=$ Mesio lingual; $\mathrm{P}=$ Palatine. 
Descriptive statistics analysis was made using collected data. WL means obtained using AL were calculated and compared to WL obtained with ALT method using measurements published by Ingle \& Bakland, that is, to ATL data, was subtracted $1 \mathrm{~mm}$ (Table I).

Descriptive statistical analysis of the data was conducted to determine the average and standard deviation. To determine if data sets are well modeled by a normal distribution D'Agostino \& Pearson normality test was used. To compare the WL means determined using AL to WL obtained from ATL-based method was executed one sample $\mathrm{t}$-test if data distribution was normal and Wilcoxon test was used if data did not pass normality test. Continuous variables between groups were compared using Independent samples t-test (normal distribution of data sets) or MannWhitney $\mathrm{U}$ test (non-normal distribution of data sets). Statistical significance was $p<0.05$. Statistical analysis was performed using R software (R Foundation for Statistical Computing, Vienna, Austria) (http://www.R-project.org/).

\section{RESULTS}

Within the time proposed for this research, 172 received endodontic treatment, corresponding to 52 mandibular second molars, 53 maxillary second molars, 35 mandibular second premolars and 32 maxillary second premolars. Of these groups, according to inclusion and exclusion criteria, 75 teeth were included in this study, corresponding to 21 mandibular second molars, 25 maxillary second molars, 13 mandibular second premolars and 16 maxillary second premolars.

WL averages obtained using AL from canals of multirooted molars were compared among them. No significant differences were observed between these measures $(p=0.887$ and $\mathrm{p}=0.426$, respectively). Comparisons of WL averages (using AL) obtained from buccal canals in maxillary second molars and mesial canals in mandibular second molars, did not show significant differences $(\mathrm{p}=0.922$ and $\mathrm{p}=0.226$, respectively) (Table II). Subsequently, WL (AL) average by sex was calculated for each root canal; means were compared between sexes. No significant differences were observed between men and women for maxillary and mandibular second premolars $\mathrm{WL}(\mathrm{p}=0.172$ and $\mathrm{p}=0.895$, respectively); a similar situation was observed when comparing the maxillary second molars root canals (by gender): $\mathrm{P}, \mathrm{MB}$ y DB $(p=0.778, p=0.187$ and $p=0.759$, respectively). In contrast, significant differences were observed when comparing mandibular second molars WL for all root canals: $\mathrm{D}, \mathrm{MB}$ y ML ( $\mathrm{p}=0.047, \mathrm{p}=0.044, \mathrm{p}=0,019$, respectively). In the three root canals mentioned, the average WL was higher in men than in women (D $1.5 \mathrm{~mm}, \mathrm{MB} 1.7 \mathrm{~mm}$ and ML $1.7 \mathrm{~mm}$ approximately) (Table III). Finally, average WL obtained using AL, were compared to mean WL based on ATL data published by Ingle \& Bakland. Statistically significant differences were found only in one canal of second maxillary molar (DB), which has a WL $1.54 \mathrm{~mm}$ larger (measured using AL) than the WL obtained using ATL value $(\mathrm{p}=0.002)($ Table IV).

Table II. Comparison of working length measures obtained with apex locator between second molar root canals.

\begin{tabular}{|c|c|c|c|c|c|c|c|}
\hline \multirow[b]{2}{*}{ Tooth } & \multicolumn{5}{|c|}{ Root canal } & \multirow[b]{2}{*}{$p^{a}$} & \multirow[b]{2}{*}{$p^{b}$} \\
\hline & $\begin{array}{c}\text { MB } \\
(\mathbf{m m})\end{array}$ & $\begin{array}{c}\text { DB } \\
(\mathrm{mm})\end{array}$ & $\begin{array}{c}\text { ML } \\
\text { (mm) }\end{array}$ & $\mathbf{P}(\mathbf{m m})$ & $\mathbf{D}(\mathbf{m m})$ & & \\
\hline Maxillary $2 \mathrm{n}^{\mathrm{d}}$ molar & 19.88 & 19.94 & - & 20.18 & - & 0.887 & 0.922 \\
\hline Mandibular $2 \mathrm{n}^{\mathrm{d}} \mathrm{m}_{\mathrm{olar}}$ & 19.81 & - & 20.50 & - & 20.33 & 0.426 & 0.226 \\
\hline
\end{tabular}

Abbreviations: $\mathrm{D}=$ Distal; $\mathrm{DB}=$ Disto buccal; $\mathrm{MB}=$ Mesio buccal; $\mathrm{ML}=$ Mesio lingual; $\mathrm{P}=$ Palatine;

$a=$ ANOVA test (comparison between 3 root canals); $b=$ One sample T-Test (comparison between mesial and buccal canals).

Table III. Working length measures obtained with apex locator in second premolars and molars.

\begin{tabular}{lcccc}
\hline Tooth & Root canal & $\begin{array}{c}\text { MWLw } \\
(\mathbf{m m})\end{array}$ & $\begin{array}{c}\text { MWLm } \\
(\mathbf{m m})\end{array}$ & $\boldsymbol{p}$ \\
\hline Maxillary 2n ${ }^{\mathrm{d}}$ premolar & Single canal & 20.56 & 19.38 & $0.171^{\mathrm{b}}$ \\
Mandibular 2n ${ }^{\mathrm{d}}$ premolar & Single canal & 20.83 & 21.00 & $0.895^{\mathrm{a}}$ \\
Maxillary 2n ${ }^{\mathrm{d}}$ molar & P & 20.04 & 20.33 & $0.778^{\mathrm{b}}$ \\
& MB & 19.50 & 20.29 & $0.187^{\mathrm{a}}$ \\
& DB & 19.81 & 20.08 & $0.759^{\mathrm{b}}$ \\
Mandibular 2n ${ }^{\mathrm{d}}$ molar & $\mathrm{D}$ & 19.77 & 21.25 & $0.047^{\mathrm{b}}$ \\
& MB & 19.15 & 20.88 & $0.044^{\mathrm{b}}$ \\
& ML & 19.85 & 21.56 & $0.019^{\mathrm{b}}$
\end{tabular}

Abbreviations: $\mathrm{D}=$ Distal; $\mathrm{DB}=$ Disto buccal; $\mathrm{MB}=$ Mesio buccal; $\mathrm{ML}=$ Mesio lingual; $\mathrm{P}=$ Palatine. WLMm= Average working length measured with apex locator in millimeters (men); WLMw=Average working length measured with apex locator in millimeters (women). $a=U$ Mann-Whitney test; $b=$ Student's $t$ Test for Independent samples. 
Table IV. Working length measures obtained using apex locator and working length measures determined using average teeth length for second premolars and molars.

\begin{tabular}{lcccc}
\hline Tooth & Root canal & $\begin{array}{c}\text { MWL } \\
(\mathbf{m m})\end{array}$ & $\begin{array}{c}\text { HWL } \\
\mathbf{( m m )}\end{array}$ & $\boldsymbol{p}$ \\
\hline Maxillary 2n ${ }^{\mathrm{d}}$ premolar & Single canal & 19.97 & 20.00 & $0.943^{\mathrm{b}}$ \\
Mandibular 2n ${ }^{\mathrm{d}} \mathrm{p}_{\text {remolar }}$ & Single canal & 20.88 & 20.40 & $0.393^{\mathrm{b}}$ \\
Maxillary 2n ${ }^{\mathrm{d}}$ molar & P & 20.18 & 19.80 & $0.225^{\mathrm{b}}$ \\
& MB & 19.88 & 19.20 & $0.089 \mathrm{a}$ \\
& DB & 19.94 & 18.40 & $0,002^{\mathrm{b}}$ \\
Mandibular 2n ${ }^{\mathrm{d}}$ molar & $\mathrm{D}$ & 20.33 & 19.80 & $0,162^{\mathrm{b}}$ \\
& MB & 19.81 & 19.90 & $0,832^{\mathrm{b}}$ \\
& ML & 20.50 & 19.90 & $0,121^{\mathrm{b}}$ \\
\hline
\end{tabular}

Abbreviations: $\mathrm{D}=\mathrm{Distal} ; \mathrm{DB}=$ Disto buccal; $\mathrm{MB}=$ Mesio buccal; $\mathrm{ML}=$ Mesio lingual; $\mathrm{P}=$ Palatine. $\mathrm{HWL}=$ Hypothetic working length by Ingle \& Bakland (2004), in millimeters (unless $1 \mathrm{~mm}$ of proposed measures); $\mathrm{MWL}=$ Average working length measured with apex locator in millimeters. $\mathrm{a}=$ Wilcoxon test; $\mathrm{b}=\mathrm{t}$-Test for one sample.

\section{DISCUSSION}

WL determination is one of the most important procedures involved in a successful ET. Several methods have been proposed to determine WL. In this research, we highlighted two methods. One of them is based on ATL data published to human permanent dentition. If the limit of root canal sealing is $1 \mathrm{~mm}$ coronal to the root apex it is accepted as clinical success. Therefore, this method to determine WL is based on subtracting $1 \mathrm{~mm}$ to ATL. The other method determines WL using an AL. There is a consensus that AL is a more precise and reliable method. Nevertheless, ATL-based method is still used in the absence of an AL. Interestingly, there are no studies that compare WL determined using AL to WL obtained from ATL. Furthermore, ATL measurements were determined in Caucasian individuals, and there are no studies supporting the use of ATL in non-Caucasian people. The aim of this research was to determine the average WL in root canals of second molars and premolars using AL, and compare it to WL determination using ATL data published by Ingle \& Bakland in Chilean individuals. Comparing the WL obtained using described methods, were found similar results. No significant differences were observed if WL was determined using AL compared to ATL-based method, except to MB canal of second maxillary molars. In this case, measurements made using AL were $1.54 \mathrm{~mm}$ larger than ATL-based method $(p=0.002)$. Our results suggest that WL determination based on ATL could be used as a reference to determine WL of second molars and second premolars that need endodontic treatment, in the studied people. There is no doubt that the most accurate way to determine a root canal WL is AL (Martins et al; Somma et al), however, an anatomical length reference must be determined, which is corroborated by instruments such as periapical radiography and AL. Awareness of reference lengths is relevant when patients need an emergency treatment, particularly if it is going to be performed by dentistry students or general practitioners, at locations that do not have adequate or the necessary equipment (i.e. AL), and/or in patients who cannot be exposed to x-ray (pregnant women) or AL (patients using a pacemaker).

No significant differences were observed in measurements by sex, except for the mandibular second molars, where the mean WL were higher in men than in women in three root canals (D $1.5 \mathrm{~mm}$, MB $1.7 \mathrm{~mm}$ and ML $1.7 \mathrm{~mm}$ longer) ( $p=0.047, p=0.044$ and $p=0.019$, respectively). The results indicate that, even though there are no statistical differences in the WL determination using both methods, differences exist in mandibular second molar root canal length according to sex. This situation must be considered by clinicians performing endodontic treatment, being aware that roots of second mandibular molars in females are shorter than males and could prevent inoculation of periapical tissues with contaminated files.

Even though the research published by Ingle \& Bakland did not mention any difference in teeth length by sex, our results show that a root canal length difference between males and females exists in some teeth. Thus, although referential measures are safe to be used in people studied, definitive WL should always be obtained from a complete analysis of each clinical case, that is, WL determined using AL must be confirmed by means of a periapical radiography considering AL cannot give any information about the curvature and direction of the root canal.

Although the sample size was limited, it is remarkable that the teeth chosen, were carefully selected according to inclusion and exclusion criteria to eliminate any bias that could affect the results. 
This study supports that ATL values could be used as referential measures of root canals of second premolars and second molars. Further research is necessary to confirm whether this situation also occurs in other teeth of the human permanent dentition. It would also be interesting to determine and compare the mean WL of human dentition by sex, to know whether there are differences in this parameter in people worldwide, considering that the normal anatomical descriptions are different depending on the individuals studied (Al-Qudah \& Awawdeh, 2009; Zhang et al, 2011).

Finally, is important to highlight that to our knowledge, this is the first research describing teeth length in South American individuals using $\mathrm{AL}$ in vivo and that it is also the first study that (in South American people), compares anatomical teeth length to a clinical measurement obtained from an AL. We encourage researchers and endodontists to replicate this research in different continental population groups with the aim of increasing the knowledge of clinical anatomy applied to endodontics and improve the prognosis of these treatments.

RODRÍGUEZ-NIKLITSCHEK, C.; CANTÍN, M.; \& OPORTO, V. G. H. Comparación de dos métodos para determinar la longitud de trabajo promedio en segundos molares y premolares. Int. J. Morphol., 33(3):1136-1140, 2015.

RESUMEN: Entre los procedimientos involucrados en un tratamiento endodóntico exitoso está la determinación de longitud de trabajo (LT). Esta debe mantenerse durante todo el tratamiento, y el extremo del canal radicular (CR) debe detectarse con precisión. Existen varios métodos para determinar LT; los investigadores han publicado la longitud total promedio (LTP) de la dentición permanente humana. Estas mediciones se utilizan como referencia anatómica. Si LT se evalúa usando una imagen radiográfica, se acepta como éxito clínico cuando el límite de la obturación radicular queda $1 \mathrm{~mm}$ coronal al ápice radicular. Un método para determinar LT se basa en restar $1 \mathrm{~mm}$ a la LTP. Otro método, que permite una determinación de LT más precisa, se realiza utilizando un localizador apical electrónico (LA). Pese a esto último, las medidas publicadas de LTP todavía se utilizan como referencia anatómica, para determinar LT en ausencia de un LA. El objetivo fue determinar LT promedio de los CR de segundos molares y premolares con indicación de endodoncia utilizando LA PropexII ${ }^{\circ}$, y comparar estas mediciones con la LT determinada utilizando el método de LTP. Se realizó un estudio descriptivo de corte transversal con una muestra no probabilística de casos consecutivos. No hubo diferencias estadísticamente significativas entre la LT obtenida con LA y el método LTP en los dientes estudiados, salvo en los canales mesio-bucales de segundos molares superiores $(19,94 \mathrm{~mm}$ promedio usando LA, 1,54 mm mayor que el método LTP: 18,40 mm; $\mathrm{p}=$ $0,002)$. El método para definir LT a través de LTP podría utilizarse para determinar LT de segundos molares y premolares en la población estudiada. Se requieren investigaciones posteriores para determinar si el método que utiliza LTP es confiable para ser utilizado en ausencia de un LA o en pacientes en los que este instrumento no pueda ocuparse.

PALABRAS CLAVE: Endodoncia; Localizador apical electrónico; Longitud de trabajo; Anatomía del sistema canalicular radicular.

\section{REFERENCES}

Abarca, J.; Zaror, C.; Monardes, H.; Hermosilla, V.; Muñoz, C. \& Cantín, M. Morphology of the physiological apical foramen in maxillary and mandibular first molars. Int. J. Morphol., 32(2):671-7, 2014.

Abella, F.; Patel, S.; Durán-Sindreu, F.; Mercadé, M. \& Roig, M. Mandibular first molars with disto-lingual roots: review and clinical management. Int. Endod. J., 45(11):963-78, 2012.

Al-Qudah, A. A. \& Awawdeh, L. A. Root and canal morphology of mandibular first and second molar teeth in a Jordanian population. Int. Endod. J., 42(9):775-84, 2009.

Ingle, J. I. \& Bakland, L. K. Endodoncia. $3^{\text {a }}$ ed. México, McGraw-Hill Interamericana, 2004

Jarad, F. D.; Albadri, S.; Gamble, C.; Burnside, G.; Fox, K.; Ashley, J. R.; Peers, G. \& Preston, A. J. Working length determination in general dental practice: a randomized controlled trial. Br. Dent. J., 211(12):595-8, 2011.

Martins, J. N.; Marques, D.; Mata, A. \& Caramês, J. Clinical efficacy of electronic apex locators: systematic review. J. Endod., 40(6):759-77, 2014.

McDonald, N. J. \& Hovland, E. J. An evaluation of the Apex Locator Endocater. J. Endod., 16(1):5-8, 1990.

Ozsezer, E.; Inan, U. \& Aydin, U. In vivo evaluation of ProPex electronic apex locator. J. Endod., 33(8):974-977, 2007.

Pereira, K. F.; Silva, P. G.; Vicente, F. S.; Arashiro, F. N.; Coldebella, C. R. \& Ramos, C. A. An in vivo study of working length determination with a new apex locator. Braz. Dent. J., 25(1):17-21, 2014.

Shanmugaraj, M.; Nivedha, R.; Mathan, R. \& Balagopal, S. Evaluation of working length determination methods: an in vivo / ex vivo study. Indian. J. Dent. Res., 18(2):60-2, 2007.

Somma, F.; Castagnola, R.; Lajolo, C.; Paternò Holtzman, L. \& Marigo, L. In vivo accuracy of three electronic root canal length measurement devices: Dentaport ZX, Raypex 5 and ProPex II. Int. Endod. J., 45(6):552-6, 2012.

Zhang, R.; Wang, H.; Tian, Y.; Yu, X.; Hu, T. \& Dummer, P. M. Use of conebeam computed tomography to evaluate root and canal morphology of mandibular molars in Chinese individuals. Int. Endod. J., 44(11):990-9, 2011.

Correspondence to:

Cynthia Rodríguez-Niklitschek

Cirujano Dentista, Especialista en Endodoncia

Docente Cátedra de Endodoncia y Especialidad de Endodoncia

Universidad Mayor

Av. Alemania 0281

Temuco - CHILE

Email: cynthia.rodriguez@mayor.cl

Received: 30-06-2015

Accepted: 06-08-2015 